\title{
Medical Secret as a Basis of Medical Confidence in Relation Doctor-Patient - a View from Healthcare System of the Republic of Serbia
}

\section{SUMMARY}

The medical secret is one of the foundations of medical ethics and medical employees' moral obligations, and it refers to the principle of not disclosing confidential information about the patient. Hippocrates considered the obligation to keep a medical secret to be the "sacred duty" of a physician. The medical secret was initially cultivated as 'the know-how to remain silent' (ars muta), while in the $18^{\text {th }}$ century it becomes a legal duty that would be sanctioned according to the criminal law. Divulging a medical secret could thus lead to a criminal conviction, the obligation of compensation, and the responsibility in front of the court for medical employees.

The main purpose of the keeping a medical secret is to protect patients' interests, which follow from his constitutional rights to human dignity and privacy. The specific importance of a medical secret is attributed to it being a foundation of patients' trust to medical employees, and this has an influence on the quality of administering medical care and on a better functioning of the medical system as a whole.

The question is now how to secure the due respect and keeping of a medical secret in such a system, that is to say, how to revise this old-fashioned concept and adjust it to the reality? It is necessary to take a number of legal, organizational and technical steps by means of which a reasonable protection of privacy would be achieved. With respect to that, it is necessary to have a continued education in the domain of medical ethics of not only all of the medical employees, but also of data scientists and lawyers, because it is only the synergetic effort that will give the desired results.

The investigated matter is primarily elaborated from the viewpoint of the Republic of Serbia healthcare system.

Keywords: medical secret, medical ethics, patient's rights, privacy, Republic of Serbia healthcare system.

* Correspondence Address: Dragana Denić, Neurological Department, General Hospital Krusevac, XII Infantry Regiment, 2/31, Krusevac 37000, Serbia. E-mail: denicd21@gmail.com. 


\section{TERMINOLOGY, HISTORY AND IMPORTANCE}

First, something briefly about terminology: why not "doctor's secret", when this term is widely accepted in our medical - ethical slang? We find that for this type of secret, nowadays it would be more appropriate to use the syntagm "medical secret", "health secret" or "professional secret of medical employees", as this includes all persons who, in this or that way, come into contact with patients, take part in his treatment, and thus find out the information they are obligated to keep as a patient's secret $(1,2,3$, 4).

The duty to keep a medical secret developed at first from the relationship itself between the doctor and the patient. It was created thanks to the very nature of the medical activity, such as "ars muta".

The earliest medical records prohibited the doctor from revealing secrets "entrusted to his ear, eye-caught or perceived by the mind". The obligation to keep a medical secret Hippocrates considered as the "holy duty" of a doctor. So, he wrote in his Oath: "What I find out or see in my work, if it does not have to be publicly known, I will hold it and keep it as a secret." (Hippocrates has a very broad definition of what counts as a medical secret because for him it implies all the facts that are known and seen in the patient's home.) This is also emphasized by all subsequent ethical codes and oaths. However, for a long time it was exclusively a moral obligation of a doctor to a patient. The problem, however, was that in the event of a violation of the ethical covenant, sanctions could not be taken $(1,5,6)$.

The conversion of the medical secret into a legal obligation happened only in the eighteenth century, much later than, for example, the corresponding obligation of the lawyer. Namely, only when the state took over people's health care, with healthcare becoming a social function, the state also took care of the laws related to the medical secret. Thus, for the first time in 1794, in the Prussian General Land Law, a penalty was determined for the revealing of a secret by "medical personnel".

In the nineteenth century, the duty of keeping a medical secret was sanctioned by the criminal law. This practice has remained until today.

The Criminal Code of Serbia (7) also contains the act of unauthorized disclosure of a secret (Article 141).

In addition, the Law on the Rights of Patients (8) regulates the duty of keeping a medical secret in Article 14 ("The Right to Privacy and Confidentiality") and 21-24 ("The right to confidentiality of data about patients' health state").

Furthermore, the Personal Data Protection Law (9) guarantees to every physical person the realization and protection of the right to privacy in relation to the 
processing of personal data (Article 2). Data relating to the health state can be processed on the basis of freely given person's consent, except in cases for which the data processing is not permitted by law even with consent. Exceptionally, these data can be processed without the consent of the person only if this is prescribed by law, with special protection measures (Article 16, paragraphs 1-3).

Finally, the medical secret became an integral part of the rules of the medical profession itself. The Code of Ethics of the Medical Chamber of Serbia (10) thus regulates the medical secret in its articles 23-25 ("Doctor and professional secret").

The basic purpose of keeping a medical secret is the protection of patient's interests, which comes out from his rights. Today, it is considered that the duty of keeping medical secret is one aspect of the realization of the right to human dignity and privacy guaranteed by the constitution (see Articles 23 and 42 of the Constitution of the Republic of Serbia) (11). The patients' right to keep medical secret as well as the right to privilege and privacy are primarily related to the principle of respect for the personality of the patient and his autonomy and the principle of "primum non nocere" (12).

To illustrate this with an example, at one point the president of the National Assembly Slavica Djukic Dejanovic told to a press agency that, as a neuropsychiatrist, she interviewed a patient, the Hague indictee Ratko Mladic, but that she cannot give details about this interview because of a professional medical secret.

The particular importance of medical secret lies in the fact that the trust of patients in the medical employees is based on it. And without this trust it would not be possible to build the appropriate relationship between a patient and a medical employee (1).

The initial discomfort in this relationship can be resolved precisely by the readiness of a physician to respect privacy. The patient should be granted privacy in the extent required by the very nature of the relationship and of the task that needs to be accomplished. The patient does not reveal a secret to a doctor because he so desires, but rather because he is constrained to do so by special circumstances, because of disease, so that he can be healed by the medical intervention. Therefore, the patient must be sure that the information about him, which he himself discloses to a doctor or allows the doctor to establish it, will be kept secret. This is based on the mutual trust between the doctor and the patient, which makes the basic assumption of the doctor's work.

By respecting the medical secret, the doctor preserves the reputation of the patient and establishes his personal authority through the trust that the patient shows him in the course of the treatment. Therefore, the doctor must never allow the patients to become victims of silence out of fear of one's indiscretion. Moreover, the patient 
does not need to specifically mention confidentiality, as this is something he already counts on!

What are the potential consequences for the patient if the secrets nonetheless come out from the medically predefined circles of their disclosure? These can vary: from a little blush to a devastated dignity; but also loss of friends, spouse, sexual partner, whole family, work (...), then stigmatization and discrimination, emotional devastation... More than enough to take the medical secret very seriously (4). The most important issue to consider is the private interest of individuals that is protected in this way.

In one case, a 25-year-old female lawyer in a private marketing firm became the main "hero" of the gossip when she went on a sick leave, because her curious colleague from the human resources department did not resist looking in the code book of the diseases by which she found out that behind the code was a gynecological intervention. By the end of the day, everyone in the firm has heard about this, and by the end of the week the news arrived in nearby cafes. Upon coming back to work, this woman had to face mocking views and ambiguous comments (13).

In another case, a young married couple, along with the mother-in-law, came to a doctor. The wife and mother-in-law entered the doctor's office, and her husband stayed waiting outside. The doctor, of course, asked all the usual questions: "Have you been suffering from any viral illness?", "Do you have Herpes, condyloma ...?” etc. The mother-in-law listened carefully. After the doctor wrote a referral for the lab, they left, but never again referred back to him for a follow-up. After a while, he found out what had happened. They divorced, the woman was forced to leave the house because the mother-in-law was telling everyone what she heard in the doctor's office, and she was told by a nurse from a clinic living in the same village that these viruses were exclusively sexually transmitted. Since then, the doctor has been receiving patients alone (13).

Citizens are often unaware of the violation of their right to privacy in health care institutions. One of the obvious examples of violation of this right was the installation of a camera directed at a gynecological table in the gynecologist's office in Jagodina. By order of the Ministry of Health, the camera was removed and the images destroyed. (13)

However, the atmosphere of trust, which facilitates the work of the doctor, also affects the functioning of the health care system as a whole, and thus serves the general interest. On the other hand, medical secrets indirectly benefit the doctor, because he can perform his professional activity only if the patient provides him with the information necessary for diagnosis and therapy. The greatest possible discretion 
should always be provided, so that the patient can give the doctor the most intimate information, which is sometimes important for the treatment (1).

Nevertheless, the focus is on protecting the patient from indiscretion. This protection is exercised through the criminal, civil and professional rights of a doctor. To be more precise, the disclosure of a medical secret may cause criminal punishment, an obligation to pay damages, and disciplinary liability before a professional medical court for doctors (1).

In addition, the Law on Civil Procedure (14) authorizes the doctor to deny giving a testimony about the facts which he is obliged to keep as a professional secret (Article 248, paragraph 1, point 3). The Law of Criminal Procedure (15) goes even further, so it says: "A person who, by his testimony, violates the obligation to keep a professional secret (religious confessor, lawyer, doctor, grandmother, etc.), is excluded from the duty of testifying unless he is exempt from that duty by a special regulation or by a statement of the person in favor of which the secret is kept" (Article 93, paragraph 1, point 2).

\section{THE PERSONS OBLIGED TO KEEP A MEDICAL SECRET}

According to the Patients' Rights Law (8), "all medical workers and their associates have the obligation to keep a medical secret. The same holds for the other employees in health institutions, private practices, organizational units of higher education institutions of health profession that perform a health care activity; for other legal entities carrying out certain activities belonging to the medical profession in accordance with the law, the organization of compulsory health insurance, as well as to the legal entity that carries out voluntary health insurance activities, in which the patient is provided with health insurance, to whom these data are available and necessary for the accomplishment of the legally established competences" (Article 21, paragraph 2).

In addition, it is considered that the obligation to keep a secret of the patient's personality is a subject to the students of the respective professions, as well as the secretaries and other persons who are by profession a doctor's assistants.

However, such an obligation is not incumbent upon persons employed as doctors' domestic help and the persons who have helped a doctor to care for one single patient.

The duty of keeping a medical secret is for the whole life, i.e. it does not stop with the end of professional activity (1). 


\section{SUBJECT OF THE OBLIGATION OF KEEPING MEDICAL SECRET}

\section{The concept of secret in general}

The concept of secret includes the knowledge of some facts that cannot be communicated to other persons without prejudice to the person concerned by the secret or to the interests of the community $(5,6)$. In other words, this term refers to an information that is known (a factual element) and which may be known (a normative element) only by certain persons.

Secrets can be categorized into: professional, employment-related and personal.

Personal secret is all that is related to an individual, his inner world, and everything that he does not want to be known about him without his consent. Facts that represent personal secret can be the most diverse and most often relate to some of the individual's personality traits, such as, for example, some physical or mental disadvantages, but also some of his thoughts, ideas or acts.

Employment-related secret concerns the data or documents which, by law, other regulation or decision of a competent authority that was based on the law declared as employment-related secret and whose disclosure would cause or could cause detrimental consequences for the employment of the individual concerned by the secret (Article 369, paragraph 4 of the Criminal Law) (7).

Professional secret also arises from employment, but is more intimately connected with the professional activity itself and it directly derives from the manner of completing this activity (secret of an attorney, of a doctor, of a priest-confessor, etc.) (5).

A medical secret is, at the same time, a professional and an employment-related secret $(5,6,16)$.

\section{The concept of medical secret}

The duty of keeping medical secret concerns the facts that are known only to a limited number of persons. These are the facts from the private sphere of a specific patient, which do not even have to be of medical importance. But the condition is that a patient has a reasonable interest worthy of protection in keeping these facts secret. This condition is met if the disclosure of the information in question could harm the patient in any way, or would hurt his mental integrity. Therefore, it would be better to exclude banalities, such as, for example, the data that someone had a cold or broke 
his leg skiing, because their disclosure does not damage the interests that are worthy of protection (17). Therefore, whether or not a disease is considered as a medical secret depends, for example, on whether the society considers it to be a shameful one, which diminishes the reputation and status of the patient in the environment in which he or she lives (for example venereal diseases, psychosis, impotence, physical illness or anomalies which cause repulsion, disgust, etc.), whether it is transmissible or not, what is the success of the treatment of this disease, and similar.

The person to whom the data relates must herself want the data not to be available to the third persons (18). Therefore, the benefit of keeping a medical secret must be appreciated according to a subjective criterion, without legal and moral evaluation, and not by an objective criterion (how would someone else refer to it, if he was a patient) (19).

As a rule, medical employees should assume that the patient has the will to keep his data secret, but this assumption can be dismissed (based on patient's statements or acts) (17).

When the patients who are incapable of judgment are concerned, as they are unable to express their will, we assume that their will is to keep the facts about them in secret. This also applies in certain cases when some facts are not even announced to a patient capable of judgment, because the information about them is medically contraindicated (for example, malicious diagnoses and prognosis).

In accordance with the Law on Patients' Rights (8), obligation of keeping a medical secret corresponds to the patient's right to privacy and confidentiality. This means that "the patient has the right to the confidentiality of all personal information, which he has informed the competent medical employee, i.e. medical associate, including those related to his state of health and potential diagnostic and therapeutic procedures, as well as the right to protection of his privacy during the implementation diagnostic tests and treatment in general" (Article 14, paragraph 1).

The Code of Medical Ethics of the Medical Chamber of Serbia (10) states that "in the professional secret are included all the doctors' knowledge about the patient and about his personal, family and social environment, as well as all information regarding determination, treatment and monitoring of diseases that the doctor acquired while exercising his profession" (Article 23, paragraph 1).

In legal theory (19), it is believed that the concept of medical secret is to be interpreted in a very broad sense, so that, in addition to information about the illness and patient, it also includes data on the personal, family, professional, economic and financial circumstances of the patient, as well as his relationships with others. So, for example, this would be data on family problems, extramarital relationship, poverty 
that is hidden by the family members, etc. Although these data do not have direct relations to the illness that is being treated, their disclosure would certainly harm the patient or it would at least be uncomfortable for the patient and would make him question his trust in the doctor. The secret, therefore, is not necessarily about the patient himself, but it can also concern the other people. The only condition is that the patient is interested in keeping the information secret.

A secret is not only the fact that someone is ill, a secret is also a fact that someone is healthy (5)!

The name and surname of the patient at the clinic are a secret, as this can cause some discomfort to the patient. This applies especially to psychiatric patients, whereby even the fact that someone is treated in the psychiatric department must be considered a secret. It can be said that this is one of the most delicate medical secrets. So, for example, if someone asks whether Petar Petrovic is being treated at the Dr Lazarevic Psychiatric Clinic, one should answer "I do not know" and refer him to the competent doctor, who will estimate what and how much he should say.

The diagnosis, as a rule, should be considered a secret. There are patients who find certain diseases shameful. Although a medical professional knows that these patients are wrong, he must respect his patients' opinions. So, what one patient is suffering from should not even be disclosed to the patients sharing the room with him, unless, of course, he does not tell them himself.

The manner of treatment, certain diagnostic procedures, which are exclusively the scope of work of doctors, are also a secret. Some think that nurses, students, pharmacists need not be familiar with the state of a patient to details, but only as much as it is necessary for the successful performance of their work. Thereof, the lower medical employees who are not often informed in detail about the essence of the disease, should refrain from commenting, as they may misinterpret some things and thereby lead both themselves and others into an unnecessarily uncomfortable situation (5).

The data on human substances are especially sensitive data on the patient's personality, as these can be used to determine identity of the person from whom they originate (Article 21, paragraph 4 of the Law on Patients' Rights) (8).

It is said that a secret is all that a medical professional sees and notices about the patient while exercising his profession. So, on the occasion of a home visit, the secret is data about the apartment, the household, the furniture, and so on (5).

Generally speaking, a doctor should not disclose a secret to anyone, not even to the family members, close friends or relatives of the patient. However, "despite the child's request that the information about his state of health is not communicated 
to his/her legal guardian, the competent medical professional is obliged, in the event of serious danger to the life and health of the child, to inform his/her legal guardian of his health status" (Article 24, paragraph 2 of the Law on Patients' Rights). Also, "members of the close family of the patient have, exceptionally, the right to inspect the medical records of their family member, if these data are of significance for their treatment" (Article 20, paragraph 4 of the Law on Patients' Rights) (8).

Medical examination of the patient and taking medical measures in general can only be attended by those medical employees, i.e., medical collaborators who directly carry out these medical activities. However, the patient can also give consent for the presence of other persons. Also, during the staying in a stationary health institution, the patient has the right to prohibit visits to certain persons (Article 14 of the Patients' Rights Law) (8).

The facts that the doctor is obliged to keep secret he ought to have found out while doing his profession. It does not matter whether the patient or a third person (e.g. a patient's wife, his employer, etc.) communicated those facts to him or the doctor discovered them with his or her own examination or insight during a home visit to the patient.

If a secret is told to a doctor, it is irrelevant where and how it is done: verbally, by writing, with pictures or certain signs, in a doctor's office, on the street, at a reception, during a specific medical procedure, or in a general conversation between a doctor and a patient. But it is necessary that this information was given to him due to his doctor's ability.

This however does not apply to the cases when a doctor finds out a secret regardless of the exercise of his profession (for example, in a private conversation, or when reading a letter addressed to a patient, etc.). However, a doctor may afterwards be obliged to keep even this information a secret, if he later provides medical assistance to the person concerned. A real functional link between the knowledge of certain facts and the exercise of the profession exists regardless of whether the doctor treats the patient accidentally (for example, as a victim of a traffic accident), voluntarily or because he is constrained to do so.

Even though the medical professional is not obliged to keep secret information that he has discovered independently of the exercise of his profession, it is better to refrain from recounting such information. As medical knowledge allows him to think differently and reach different conclusions, his words have a greater "weight" in this case. In addition, a tendency to recount such intimate information is in itself not a nice personal trait, so medical professionals should try to stay out of recounting the information about the illnesses of others. Finally, there is a possibility of false 
memory, when a person cannot differentiate what he found out at work from what he heard from friends.

\section{Unique and shared secret}

Depending on the relationships that occur during medical intervention, a unique and shared secret may be distinguished $(5,6,16)$.

A secret was once unique, i.e. it was only between a patient and a certain medical profession, usually a doctor who was the only one who discovered it in his work and contact with the patient. It should not even be told to other doctors, so for example the Consilium examination of the patient requires his consent (5).

Nowadays, however, the situation is very different. As modern medicine has been divided into many specialties and the communication between several medical employees is necessary during the medical treatment, the term of the shared secret has been introduced. Team work, consultations, transferring patients from one health institution to another will certainly cause delivering data and transferring secrets from one to another.

Also, the concept of shared secret also came with the introduction of an obligation to provide various information, for example, on health insurance services. The medical secret is, therefore, divided among several persons who in the process of work discover it and it is an ethical and legal obligation of all of them to keep it.

The point of view on the acceptance of classified secrets from many parties is criticized. The shared secret should not be exaggerated, and only the justifiably necessary data should be shared with other medical professionals, in order to keep the individual confidentiality between the doctor and the patient (5).

\section{Coded and service diagnoses}

By socialization and bureaucratization of medicine, many medical secrets have become available to the public, because in some medical documents (for example, to justify absence from work) there is a diagnosis that other people can read. To avoid any discomfort for the patients, coded diagnoses and statements are often used, as well as service diagnoses (5).

Coded diagnoses and statements are used when a doctor does not want it to be known what the patient is suffering from. Sometimes he hides it from the patient or from someone from his environment, who could come to a medical examination. 
Thus, for example, instead of diagnosis of alcoholism, the doctor writes the code from the International classification of diseases. Psychiatric disorders, malignancies and some infectious diseases are also written with appropriate abbreviations or codes.

Service (incorrect) diagnoses are used when the doctor does not want anyone to know why the patient is treated at the clinic. In these cases the real diagnosis is written in anamnesis and it is indicated that a service diagnosis is written on the discharge from the clinic document, which is usually similar to the correct one, but slightly modified (for example, instead of schizophrenia it is written psychasthenia, etc.) $(5,16)$.

\section{REVEALING OF MEDICAL SECRET}

A secret is revealed by someone who makes it available to a third person who does not know about it, even when that third person is among the persons who are obliged to keep the secret. For example, this can be done by giving oral or written notifications to another, confirming someone else's assumptions or other information, by transferring the medical documents to someone else, by telephoning about the circumstances with a secret character in the presence of a third person who can identify the patient to whom the circumstances relate to etc.

In hospitals, attached to the bed of each patient, there are so called temperature lists with a large amount of the patient's data (name and surname, the year of birth, diagnosis, temperature, pulse, blood pressure, administered drugs, dates of surgical interventions and various laboratory tests, etc.). These lists are open and accessible to anyone who comes to visit this or other patient in the room.

The act of revealing a secret can also be done unintentionally (for example, if the doctor leaves the patient's medical records unlocked and thus allows for an unauthorized third person to have a look or take it out, or if the doctor doesn't close the door of his surgery, so that the conversation with the patient can be overheard in the waiting room, etc.) (1).

It is irrelevant how the secret was revealed, whether a secret was revealed to one or more persons, whether its disclosure could objectively cause or it did in fact cause some harmful consequences, etc., but these circumstances can, as a rule, be evaluated as aggravating.

In principle, the exchanges of information about secret facts between doctors working in the team, between the general doctor and the specialist doctor, as well as between the doctors who alternately cure the same patient are not considered as disclosures of a secret. On the other hand, exchanging such information with the other doctors is considered inadmissible (19). 
However, doctors have a legitimate need for an exchange of experiences, which is why they are allowed to describe cases to each other. But, this can only be done in such a way that the patient's anonymity is guaranteed, i.e. without mentioning his name or any other information on the basis of which one could identify the person in question.

Publication of the data of a patient in scientific research documentation, professional publications and teaching is possible only with the consent of the patient and with the respect to his personal dignity (see Article 25, paragraph 2 of the Code of Medical Ethics of the Medical Chamber of Serbia) (10). If thereby photos are published, they must also be adjusted so that the person they represent could not be recognized.

\section{POSTMORTAL DUTY OF KEEPING A MEDICAL SECRET}

The Code of Medical Ethics of the Medical Chamber of Serbia (10) prescribes that the doctor is obliged to keep a professional secret even after the patient's death (Article 23, paragraph 2).

In the Geneva Declaration (World Medical Association) for example, an "absolute secrecy" is required, and according to this medical document, the doctor is obliged "not to reveal the secrets entrusted to him even after the patient's death." Similar recommendation can be found in the International Code of Medical Ethics (also formulated by the World Medical Association) (4).

In some Criminal Laws (e.g. German), this is explicitly prescribed. Such an attitude should be adopted even without the legal regulation, because the right of a person to privacy is not extinguished with his death.

In addition, the patient's consent that someone disposes with a secret from the domain of his own life is a strictly personal right and, as such, it cannot be given after his death. Then he is no longer able to relieve the doctor of the obligation of keeping a secret, and it has been argued that his successors or close persons cannot do it either. Therefore, publications with description, to the ugliest details, of the last hours of agony and dying, either in biographies, literature, memoirs or in scientific papers, are inadmissible.

However, the post-mortem doctor's obligation for silence can be abolished by the lifelong, explicit, or taciturn statement of the deceased patient. It is also possible to assume that the patient would have agreed to reveal a secret, which is a matter of the judgment of the doctor and persons close to the patient (19). 
Whether the interest in keeping the secret is lost with the patient's death or it still exists should be conscientiously estimated in each case. However, in case of doubt, a doctor should always opt for the post-mortem obligation of silence (19).

\section{REASONS THAT JUSTIFY THE REVEALING OF A MEDICAL SECRET}

\section{General overview}

The duty of keeping a professional secret is not absolute (1).

Thus, for example, the Criminal Law of Serbia (7) determines that one "who reveals a secret in general interest or interest of another person, which is more important than the interest of keeping a secret" (Article 141, paragraph 2), will not be punished.

In addition, the Law on Patients' Rights (8) states that the competent medical professionals and medical associates "can be exempted of the duty of keeping a medical secret only on the basis of written consent of the patient, or his legal representative, or on the basis of a court decision" (Article 22, paragraph 1).

Finally, the Code of Medical Ethics of the Medical Chamber of Serbia (10) stipulates that the doctor is free from keeping a professional secret if the patient or his legal representative consults the patient in writing, if the act of keeping a secret endangers the life or health of the patient or other people, and if he is obliged to reveal the secret by the law. A secret shall be revealed only to the necessary extent and only to the appropriate person to whom this information is necessary in order to prevent the undesirable consequences. In case of release from professional secret, the doctor should inform the patient about this (Article 24).

The act of a doctor who reveals a secret for justified reasons is thus not unauthorized. Some of these reasons are determined by special law regulations (e.g. regulations on compulsory reporting and registration of certain diseases), while others arise from general circumstances that are able to exclude unlawfulness. These second will be explained in more details below in this paper.

\section{Consent of the authorized person}

The patient's consent, which arises from the right of self-determination, frees the doctor from the obligation of keeping a medical secret (17). 
Statement of consent may be given in any form, explicitly or by any conclusive act. Thus, for example, if a patient names his doctor for a witness, he tacitly releases the doctor from the obligation of keeping a medical secret. This is the case as well when the patient, following the instructions of his chosen doctor of general medicine, goes to the specialist. The patient then tacitly agrees that the findings obtained from a specialist can be viewed by the chosen doctor of general medicine.

Finally, the consent can be revoked later (1).

\section{Assumed consent of the authorized person}

The assumed consent of an authorized person is particularly important when a patient is unable to make his own statement (e.g., he died, lost consciousness, he is mentally ill, etc.). But sometimes also the doctor can deduce from the circumstances that the patient has no interest in keeping his secret (19).

The content of the presumed will can be deduced from the patient's personal circumstances, from his own interests, desires, needs and values. Thereby the only important thing is individual hypothetical will, and not some objective criterion which would presuppose the so-called rational patient (19).

\section{State of ultimate necessity}

A medical secret can be revealed when a more urgent public or private interest is threatened by a certain danger which can be eliminated only by the disclosure of the secret. A secret disclosure should be thereby an appropriate means of eliminating danger.

Such are, for example, the following cases: the detection of a patient's mental illness in order to accommodate him in the appropriate institution because he represents a serious danger for someone in his environment; informing the competent administrative authority about the serious illness of a patient which makes him unable of driving a motor vehicle and dangerous to other road users (after an air accident in the French Alps, the investigation showed that a doctor confirmed that the copilot of the Germanwings was suicidal a few years before that event); informing the police about the abuse of children by the patient, especially when there is a danger of repeating it.

A state of extreme necessity justifies, for example, that a doctor informs the patient's wife that her husband is infected with an HIV virus because the life and health of 
a woman are more valuable than a doctor's duty to keep a secret. (This should be applied to the other infectious diseases too.)

The Patients' Rights Law (8) exceptionally allows the competent medical professional to inform about the health status of the patient the adult member of his close family, even in case when the patient did not give consent to the communication of his health information, but the communication of these data is necessary for the avoidance of health risk for a family member (Article 22, paragraph 3).

With respect to this, the American Psychiatric Association has issued appropriate instructions. The case could be similar with other serious sexually transmitted diseases. The Statement of the World Medical Association on abuse and neglect of children (...) gives not only the right, but also obliges the doctor to disclose a medical secret to the authorized body of the community in certain cases and by a certain procedure (12).

\section{Defending own justified interests}

There are cases when a patient constrains a doctor into suing him for not paying honorarium, when he initiates a press campaign against the doctor, or when he demands a doctor's compensation for the damage caused by treatment, arguing that not all undertaken medical measures have been indicated. Then the doctor has the right to expose the secret facts in order to confront the false claims or unjustified requests of the patient, or to achieve his right to a honorarium (1).

\section{CONCLUSION}

The concept of professional secret, as well as any other form of discretion related to the profession, is nowadays understood in very broad terms. The scope of the protection of professional secret is not determined exclusively by special legal norms, but also by the scope of the general personal rights. However, personal rights and human dignity of individuals sometimes come into a mutual collision, which does not allow their overall respect. On the contrary, such collision requires the measurement of the value of conflicting interests and the sacrifice of the weaker to the benefit of the superior interest. The right of a patient to privacy and human dignity is often suppressed by some stronger right and more valuable interest, his or someone else's. It is sometimes forced to be withdrawn, for the reason that is, most often, subsumed under the state of extreme necessity (1). 
In addition, the duty of keeping professional secret is weakened by general social progress and progress of the medical activity itself. As health and social security is more massive and division of work in medicine is more complete, the private sphere of the patient is increasingly endangered. Compulsory health insurance has reversed the two-way relationship of a doctor-patient in a three-way relationship. In that way the duty of keeping professional secret is considerably relativized. Health insurance and public health care of citizens require rigorous evidence of disease and patient, systematic reporting and registration. Health and social security employees also have an obligation to keep information about the patient confidential, and the socalled coded diagnoses and reports are often used. Finally, electronic data processing and medical documentation make serious obstacles to the obligation of keeping a professional secret. Endangered in many ways, this obligation is, however, somewhat maintained and continued (1).

In the upcoming period, information technology will create data production that will seamlessly integrate in our lives, both at work and at home. More and more available technology will create large databases of sensitive data. By introducing private health and life insurance, a large number of lawsuits concerning the protection of personal data are expected. "The set of medical laws" should be coordinated with the European standards (20).

Medical secret is today greatly challenged. Moral relativism of modern society leads to a discrepancy between declarative acceptance of the moral obligation of keeping medical secret and real behavior. A propensity to gossiping is not the only reason why confidential information about patient "leaks" to the public. The health care system itself is porous in this respect and it is very difficult to prevent "cracks" in this complex and bulky mechanism. Therefore, it is increasingly proposed to revise the term and formulation of the principle of medical secret, so that, as one of the protectors of this idea, Mark Sigler, says - this "worn-out concept" can finally be compared to reality (4).

The division of medicine into a lot of specialties and massive modern diagnostics lead to an increase in the number of people who are in contact with the patient and his medical documentation. It is said that there are about 180 different specialist branches of medicine, and the patient is only one, indivisible. It is clear that in such conditions of treatment of a patient it is easy to lose the sense of personal secret in relation to a medical secret (21).

Thus, for example, in one case, Sigler, after research, found out that no less than 75 people, only within the hospital, in one way or another, but always for justified reasons, came into contact with a patient's medical record. When the patient, who was otherwise very worried that information about the nature of his illness might 
reach those who "are not concerned by it", was explained that these were people whose involvement in the treatment simply could not be avoided, that is to say, everything was done according to the protocols in force, the patient asked resigned: "Would you, please, explain me what do you, as doctors, mean under - a medical secret?" (4)

The question is, therefore, not at all whether the medical secret should be revised, reformulated, redefined ... (this revision is absolutely necessary) but how to ensure its consistent respect/preservation (4). Everything should be done to ensure patient's data is protected in order to prevent their misapplication by third persons (12).

It is necessary to undertake a series of measures of legal, organizational and technical nature, which would achieve a reasonable measure of protection of privacy, because absolute privacy is impossible to guarantee. In practice, the doctor's secret should be strengthened by the basic principles of medical ethics and deontology. This conscience refers to specific people, in this case the doctors and the moral status of their profession. The best results could be achieved by educating medical employees and the general public in the fields of morality and ethics, and by insisting on the realization of desired cultural standards at the national level (2). It is necessary to educate medical employees, IT professionals, but also lawyers, because only the synergistic effort will give the desired results (20).

\section{LITERATURE}

1. Radišić, J.: Medical law, Second revised edition, Belgrade, 2008.

2. Sanjug, J.: "Doctor's Secret”, Gynaecologia et Perinatologia, no. 4/2013.

3. Šeparović, Z.: Boundaries of Risk - Ethical Approaches to Medicine, Zagreb-Čakovec, 1985.

4. Turza, K.: Medicine and Society - Introduction to Medical Ethics, Belgrade, 2015.

5. Marić, J.: Medical Ethics, Belgrade, 1988.

6. Milovanović, D. P.: Medical Ethics, Belgrade, 1976.

7. The Criminal Code ("Official Gazette of the Republic of Serbia", No. 85/2005, 88/2005 - cf., 107/2005 - ispr., 72/2009, 111/2009, 121/2012, 104/2013, 108 / 2014 and 94/2016).

8. The Law on Patients' Rights (“Official Gazette of RS”, No. 45/2013).

9. Law on Protection of Personal Data ("Official Gazette of the Republic of Serbia”, No. 97/2008, 104/2009 - other law, 68/2012 - decision US and 107/2012).

10. Code of Medical Ethics of the Medical Chamber of Serbia ("Official Gazette of the Republic of Serbia", No. 104/2016).

11. The Constitution of the Republic of Serbia ("Official Gazette of the Republic of Serbia”, No. 98/2006).

12. Kaličanin, P.: Medical Ethics and Medical Law, Belgrade, 1999.

13. Medical secret, Presentation for judges of the courts of honor of the Medical Chamber of Serbia, http://www.lks.org.rs/Storage/Global/Documents/Prezentacije/prezentacija\%20za\%20sudije\%20 sudova\%20casti\%20LKS\%20inaf-1. pdf (accessed: 10 November 2017) 
14. Law on Civil Procedure ("Official Gazette of the Republic of Serbia”, No. 72/2011, 49/2013 - decision US, 74/2013 - decision US and 55/2014).

15. Code of Criminal Procedure ("Official Gazette of the Republic of Serbia" No. 72/2011, 101/2011, $121 / 2012,32 / 2013,45 / 2013$ and 55/2014).

16. Nenadović, M. M.: Medical Ethics, Belgrade, 2007.

17. Honsell, H. (ed.): Handbuch des Arztrechts, Zurich, 1994.

18. Čizmić, J.: «The right of patients to be informed, with particular reference to the protection of the confidentiality of data on the patient's health status", Proceedings of the Law Faculty of the University of Rijeka, no. 1/2008.

19. Laufs-Uhlenbruck: Handbuch des Arztreclits, 3. Auflage, Munich, 2002.

20. Lazić, M.: Protection of personal data of patients in European and Serbian law. http://www.prafak. ni.ac.rs/files/nast_mat/Medicinska_licna_prava.pdf

21. Pejaković, S.: Forensic Expertise, Belgrade, 1986.

\section{Medicinska tajna kao temelj medicinskog povjerenja unutar odnosa liječnik- -pacijent - pogled iz zdravstvenog sustava Republike Srbije}

\section{SAŽETAK}

Medicinska tajna je u osnovi medicinske etike i moralne obveze zdravstvenih radnika, a odnosi se na princip čuvanja povjerljivih informacija o pacijentu. Obavezu čuvanja medicinske tajne još je Hipokrat smatrao „svetom dužnošću“ liječnika. U početku njegovana kao „vještina šutnje“ (ars muta), od 18. stoljeća postaje i pravna obveza sankcionirana u krivičnim zakonicima. Otkrivanje liječničke tajne može uvjetovati krivičnu kaznu, obvezu naknade štete i disciplinsku odgovornost pred staleškim sudom za liječnike.

Osnovna svrha čuvanja medicinske tajne je zaštita pacijentovih interesa, što proizlazi iz njegovih ustavom zagarantiranih prava na ljudsko dostojanstvo i privatnost. Specifični značaj medicinske tajne leži u tome što na njoj počiva povjerenje bolesnika u zdravstvenog radnika, a to utječe na kvalitetu obavljanja zdravstvene djelatnosti i bolju funkcionalnost zdravstvenog sustava u cjelini. Postavlja se pitanje kako u takvom sustavu osigurati dosljedno poštovanje i čuvanje medicinske tajne, odnosno kako jedan ,pohabani koncept“ revidirati i primjeriti realnosti? Potrebno je poduzeti niz mjera pravne, organizacijske i tehničke prirode, kojima bi se postigla razumna mjera zaštite privatnosti. $S$ tim u vezi neophodna je kontinuirana edukacije iz medicinske etike svih medicinskih zaposlenika, ali i informatičara i pravnika, jer će samo sinergijski učinak dati željene rezultate.

Istraživana građa prvenstveno je elaborirana iz perspektive zdravstvenog sustava Republike Srbije.

Ključne riječi: medicinska tajna, medicinska etika, prava pacijenta, privatnost, zdravstveni sustav Republike Srbije. 